\title{
KONSEP KEADILAN TUHAN: STUDI PEMIKIRAN TEOLOGI ABU MANSUR AL-MATURIDI
}

\author{
AFRIZAL MANSUR, ANDI SAPUTRA \\ Fakultas Ushuluddin \\ Universitas Islam Negeri Sultan Syarif Kasim Riau \\ afrizal.m@uin-suska.ac.id, andisaputra.bm@gmail.com
}

\begin{abstract}
This research presents the study of God's justice, a perception of al-Maturidi on the relation between human actions and His absolute will. Departing from his belief that God is the Most Just (al-'Adl) and the Most Wise (al-Hakim), alMaturidi stated that he would not commit arbitrary acts. Opposing the Mu'tazilah who, without the slightest acknowledgment of God's intervention in human actions, also al-Asy'ari with the thought that humans are only acting as a line of destiny, al-Maturidi tried to dissolve these extremist views by proposing the concept of masyi'ah and His pleasure. For him, God and humans have contributed to the actions that are realized. If the first one provides a variety of potentials in humans, then the role of humans with will (masyi'ah) is to choose between doing good or evil. The availability of space to choose is what in the view of al-Maturidi makes it natural that there is a human obligation in front of The God.
\end{abstract}

Keywords: al-Maturidi, Tuhan dan Keadilan.

\section{PENDAHULUAN}

Tidak lagi diragukan bahwa di antara substansi utama dari terma Ahlu al-Sunnah wa al-Jama'ah (Sunni) adalah serangkaian pemikiran keagamaan (Islam) yang disandarkan kepada Abu Mansur alMaturidi (w. 944.M) (Rahman, 2000) atau dikenal dengan sebutan Maturidiyah. Mulai dari pembicaraan berkenaan dengan sifat Tuhan, perbuatan manusia, hingga keadilan
Tuhan atas kehendak (iradah) dan kuasa (qudrah) Nya. Karenanya, menjadi wajar jika kemudian alMaturidi dianggap sebagai teolog Muslim yang juga berjasa besar dalam menguatkan patri bangunan teologi Sunni, setelah tokoh utamanya Abu Hasan al-Asy'ari (873-935.M).

Lazimnya terjadi dalam perbincangan kalam, hubungan serta keterkaitan antara manusia 
dan Tuhan seakan menjadi tema bahasan utama yang menempati rak tertinggi perdebatan: Tuhan dan manusia adalah objek yang begitu seksis di altar perbincangan teologis. Kenyataan ini misalnya didukung oleh fakta bahwa sekalipun persoalan yang dibahas pada mulanya ber-tema-kan seputar problematika keimanan, kebebasan manusia dan juga takdirnya, keseluruhan persoalan yang kemudian dimunculkan dari sana tetap bermuara pada apa yang dikenal dengan istilah "keadilan Tuhan". Agaknya, ini merupakan intisari dari teologi itu sendiri.

Menjadi

pentingnya

pembahasan dimaksud, misalnya disebabkan adanya implikasi perbuatan manusia terhadap keimanan pada dirinya. Sebuah masalah yang mulanya dimunculkan kalangan Mu'tazilah (Izutsu, 1986) ketika mempertanyakan status (baca; kedudukan) pelaku dosa besar-apakah tetap mukmin ataukah telah kafir-yang pada gilirannya melahirkan ragam faksi teologi (firqah) di tubuh umat Islam. Sebagaimana Murji'ah dan Asy'ariyah, Qadariyah dan Jabariyah, Maturidiyah turut andil dalam membincangkan masalah ini, termasuk mengenai ada tidaknya hubungan antara perbuatan manusia dan kehendak mutlak Tuhan.

Pada saat bersamaan, isu terakhir di atas juga berkenaan dengan Tuhan dan keadilan. Sebagai seorang teolog mumpuni, al-Maturidi memiliki pandangan tersendiri mengenai keadilan Tuhan. Layaknya teolog Muslim kebanyakan, dia meyakini Tuhan adalah Maha Bijaksana dan karenanya segala kehendak yang menjadi pilihanNya tidak akan pernah berbenturan dengan prinsipprinsip fundamental keadilan. Pada saat yang sama, dia juga dikatakan sebagai teolog Sunni pertama yang menyuarakan teori pengetahuan dalam teologi Islam di mana dalam penyebutan sumber pengetahuan itu digunakan istilah sam (tradisi) dan 'aql (akal) (Masturin, 2014). Berbeda dari pemakaian istilah yang umumnya ditemukan.

Menariknya, sekalipun Maturidiyah dianggap bagian eksponen inti dari pemahaman teologi yang berlaku dan di-baku-kan di kalangan Sunni, pemikiranpemikiran teologis Abu Mansur alMaturidi (selanjutnya disebut alMaturidi) seakan tidak lebih familiar dibandingkan rekan sejawatnya, alAsy'ari lewat paham keagamannya, Asy'ariyah. Padahal jika dibaca secara seksama, konsepsi alMaturidi tentang teologi memiliki keunikan serta kharakteristik tersendiri, seperti ketika ia mengartikulasikan pemikiranpemikiran yang tentunya berkaitan dengan persoalan utama ketuhanan (teologi).

Sejalannya pandangan alMaturidi dengan kalangan Mu'tazilah dalam hal perbuatan manusia atau bahkan lebih dekat dengan pendapat kelompok Asy'ariyah mengenai sifat-sifat Tuhan, menjadi semacam indikator penting bagaimana al-Maturidi memiliki posisi tersendiri di wilayah pemikiran kalam. Karenanya, menjadi wajar jika Harun menyebut bahwa alMaturidi tidak sepenuhnya bersifat Asy'ariyah atau menjadi lawan bagi Mu'tazilah, tetapi berada pada posisi di antara keduanya (pertengahan) (Nasution, 2012). Dia tidak selalu condong kepada Mu'tazilah, juga tidak pula selamanya meng-amin- 
kan pandangan-pandangan

Asy'ariyah.

Sekalipun pada gilirannya paham keagamaan ini (Maturidiyah) terbelah menjadi dua haluan, yakni aliran Maturidiyah Bukhara dan Maturidiyah Samarqand, hal itu tidak lantas menjadikan al-Maturidisebagai pribadi-memiliki dualisme pandangan, terutama berkaitan dengan persoalan keadilan Tuhan. Karenanya, menjadi penting untuk mengkonsepsikan pemikiran utuhnya mengenai hal ini. Selain berupaya mendapatkan kemurnian pandangan dari al-Maturidi sendiri, usaha yang demikian juga dalam rangka menempatkan al-Maturidi pada posisi sejajar dengan al-Asy'ari di ranah teologi.

Jika ditelusuri akar historis (genealogi) nya, sejatinya persoalan dimaksud menjadi di antara agenda terpenting dari misi kenabian Muhammad s.a.w. Bahkan, jika boleh dikatakan, merupakan esensi dari substansi utama Islam sendiri. Ini karena tujuan dari diturunkannya Islam sebagai kiblat pemikiran dan keimanan manusia adalah dalam rangka menciptakan umat terbaik (khairu ummatin) yang selain didasarkan pada prinsip ke-Esa-an Tuhan (tauhid), juga berasaskan pada nilai kesetaraan dan keadilan (Armstrong, 2002)

\section{BIOGRAFI INTELEKTUAL AL- MATURIDI}

Dilahirkan di daerah Maturid, Samarkand (sebuah kota besar di Asia Tengah), membuatnya dikenal dengan nama lengkap Abu Mansur Muhammad bin Muhammad bin Mahmud al-Maturidi al-Samarqandi (Mufid, 2013). Kurangnya informasi yang beredar mengenai sejarah hidup terutama masa kelahirannya, melahirkan polemik tersendiri di kalangan sejarawan. Harun misalnya, meletakkannya pada pertengahan kedua abad ke sembilan (Nasution, 1986). Pun begitu dengan tahun wafatnya, ada yang menuliskan 333.H (944.M), (Gibb, 2008), didapati pula yang menetapkan di tahun 248.H (862.M) (Hamka, 2007). Namun demikian, terangnya, dia hidup saat di mana kehidupan intelektual dan spiritual Islam tengah mengalami stagnasi pemikiran keagamaan (Rahman, 1984).

Mengenai riwayat pengembaraan keilmuannya, alMaturidi menerima pendidikan yang cukup baik dalam berbagai ilmu pengetahuan Islam di bawah bimbingan empat ulama terkemuka di masanya, yaitu Syekh Abu Bakar Ahmad ibn Ishaq, Abu Nashr Ahmad ibn al-'Abbas ibn al-Husain al-Ayadi al-Ansari al-Faqih al-Samarqandi, Nusair ibn Yahya al-Balkhi (w. 268.H/881.M) dan Muhammad ibn Muqatil al-Razi (w. 248.H/862.M) (Hamka, 2007). Namun demikian, dikarenakan kurangnya informasi mengenai kehidupan pribadi alMaturidi juga keluarganya, menyebabkan sketsa biografinya menjadi lebih ringkas dibanding sederetan nama teolog Muslim kenamaan lainnya.

Berbeda dari ulama kebanyakan dengan usia tidak lebih dari 65 tahun, sebut saja Imam alSyafi'i yang meninggal dunia pada usia 54 tahun, selisih satu angka dengan Imam al-Ghazali (55 tahun), ataupun Imam al-Bukhari di usia 62 tahun, al-Maturidi merasakan kehidupan bahkan sampai umurnya berkepala delapan (86 tahun) (Nasir, 
2010). Barangkali, kenyataan ini pula yang menjadi semacam ruang luas 'sosialisasi' pandangan dan gagasan teologisnya. Sebagaimana telah dikemukakan, sekalipun nantinya pengikut paham keagamaan al-Maturidi terbagi pada dua faksi (Maturidiyah Samarkand dan Bukhara), hal itu menunjukkan betapa sebenarnya ia hadir di pikiran para Muslim yang notabenenya adalah bagian dari firqah Ahlu alSunnah wa al-Jama'ah.

Sebagaimana telah dinyatakan di depan, al-Maturidi merupakan sosok teolog yang kapasitas keilmuannya diperhitungkan di dunia teologi Islam (ilmu kalam), utamanya berkaitan dengan penyebutan firqah Ahlu al-Sunnah wa al-Jama'ah. Dia tidak saja founder dan pembela dari kelompok keagamaan tersebut, tetapi juga sosok yang berhasil melahirkan beberapa pemuka kalam ternama sebagai penerusnya. Sebagaimana dikemukakan oleh Watt, mereka adalah al-Hakim alSamarqandi (w. 953.M), Abu al-Yusr al-Bazdawi (1030-1100.M), Najm alDin Abu Hafs al-Nasafi (10681142.M), juga Abu Mu'in al-Nasafi (w. 1115.M) dan al-Ushi (Watt, 1985).

Adapun mengenai dominasi warna keilmuan (Islam) nya di bidang fikih dia adalah penganut mazhab Hanafi; sebuah aliran yurisprudensi (himpunan pemahaman hukum) Islam yang dinisbatkan kepada nama pendirinya, Imam Abu Hanifah (w. 150.H/767.M). Menurut Sahilun A. Nasir, kecenderungan al-Maturidi kepadanya disebabkan tanah kelahirannya (Samarkand) merupakan arena perdebatan kalangan Hanafiyah dengan pengikut mazhab Syafi'iyah, sebagaimana juga tempat terjadinya perseteruan antara kelompok ahl alhadits dan Mu'tazilah di mana pada gilirannya menampakkan kaitan yang erat antara al-Maturidi dan Imam Hanafi dalam hal keilmuan, utamanya terkait dengan persoalanpersoalan teologi (ilmu kalam) (Nasir, 2005).

Oleh sebagian penulis, alMaturidi dinyatakan sebagai keturunan Abu Ayyub al-Anshari, seorang sahabat Rasul Muhammad s.a.w., di Madinah. Pendapat ini diperkuat oleh fakta bahwa sebagian kaum kerabat al-Maturidi yang tinggal di Samarkand adalah orangorang yang berasal dari Arab Madinah. Tidak sebatas menjadi pengikut paham keagamaan Hanafiah, pemikiran-pemikiran alMaturidi tentang teologi dipandang ikut andil dalam dinamika dan diskursus kalam di masanya (Zuhri, 2010).

Pengaruh pemikiran Abu Hanifah pada diri al-Maturidi seperti tampak pada orientasi sikapnya yang cenderung, seperti halnya kalangan Mu'tazilah, mengedepankan rasionalitas dalam sistem teologinya (Farida, 2014). Karenanya tidak mengherankan jika dalam sejumlah pemikiran keagamaan, al-Maturidi dianggap lebih dekat dengan corak pemahaman teologi Mu'tazilah, sekalipun tidak seutuhnya. Rasionalitas pemikirannya itu dapat disaksikan pada serangkaian pemikirannya tentang keyakinan (baca; agama), mulai dari prinsip utama keberagamaan dalam Islam (tauhid), sifat-sifat Tuhan, hubungan antara manusia dan Tuhan, serta beberapa aspek lain yang berkaitan dengan ilmu kalam (teologi Islam). 


\section{Warisan Karya Tulis Al- Maturidi}

Menurut Harun, karangankarangan al-Maturidi belum lagi dicetak dan masih dalam bentuk MSS (Makhtutat). Adapun di antara MSS itu adalah Kitab al-Tauhid dan Kitab Ta'wil Al-Qur'an, sementara Risalah fi al-Aqa'id dan Syarh alFigh al-Akbar dianggap pula sebagai buah karyanya (Wojcik, 2010). Menurut Agata dan Lukasz, kitab pertama didominasi dengan penjelasan tentang ide terpenting Islam yakni konsep ketuhanan, tauhid. Lebih jauh, dia bahkan mengkritik dengan keras semua bentuk dualisme (dualism) pandangan (Wojcik, 2010). Adapun karya keduanya itu merupakan sebentuk ringkasan utama dari magnum opus teologi (Kitab alTauhid) nya (Thomas, 2008).

Adapun karya tulis lain yang membincangkan persoalanpersoalan dasar keagamaan (Islam) dan diyakini milik al-Maturidi di antaranya Kitab al-Ushul, Kitab alBayan wahm al-Mu'tazilah, Kitab alRadd 'ala al-Qaramithah, Kitab alRadd al-Awa'il al-'Adillah li al-Ka'bi, Kitab al-Radd al-Tahab al-Jadal li alKa'bi, Kitab al-Imamah li Baina alRawafid, Rad al-Ushul al-Khamsah li Abiy Muhammad al-Bahiliy, Rad alWa'ad al-Fussaq li al-Ka'bi, Kitab alJadal fi Ushl al-Fiqh dan Kitab alMa'akhiz al-Shara'i fi al-Fiqh (Hamka, 2007).

\section{Sistem Pemikiran Teologi Al- Maturidi}

a. Ke-Esa-an Tuhan (Tauhid)

Sekalipun terdapat perbedaan pendapat tentang ada atau tidaknya sifat-sifat Tuhan, seperti menjadi tema perdebatan antara Mu'tazilah dan Asy'ariyah, juga Maturidiyah, tetapi hal ini sesungguhnya wujud dari kesamaan pandangan mereka tentang Tuhan. Al-Maturidi pun memandang Tuhan sebagai tunggal, Esa. Ringkasnya, perdebatan hanya terjadi di ranah pemahaman dan bukan unsur fundamental (esensi) dari makna tauhid itu sendiri. Jika penafian sifat oleh Mu'tazilah adalah dalam rangka memurnikan kesucian Tuhan dengan menghindari kemungkinan munculnya ta'adud alqudama (banyaknya yang qadim), maka kehendak yang sama juga menjadi dalil menetapkan adanya bagi al-Asy'ari dan al-Maturidi.

Hampir dapat dipastikan bahwa tidak ada seorangpun dari ahli kalam (mutakallimin, teolog) yang meragukan kepastian adanya Tuhan dan ke-Esa-an dzatNya. Ini karena umumnya mereka mengukuhkan pandangan bahwa Tuhan mesti ada dan harus pula merupakan Yang Maha Esa (Karim, 2014). (tiada berbilang). Sebagaimana telah dinyatakan pada uraian sebelumnya, Kitab al-Tauhid al-Maturidi adalah wujud nyata keyakinan dan pembelaannya mengenai hal ini. Bahkan, jika bersedia jujur mengucapkan, prinsip demikian dapat disaksikan sekalipun hanya lewat judul yang dia berikan pada karyanya ini.

David Thomas menyebut kelahiran Kitab al-Tauhid al-Maturidi sebagai respon terhadap realitas plural di masanya, termasuk kaitannya dengan ragam aliran teologi dan keyakinan. Jadi, selain bermaksud menjelaskan konsepsi tauhid kepada sesama kelompok keagamaan Islam (aliran, firqah kalam) yang ada, dia sekaligus memberi bantahan terhadap penganut agama lain kala itu, utamanya Kristen (Thomas, 2008). 
Menjadi semakin kentara karenanya, pemahaman akan Tuhan dalam persepsi al-Maturidi yang tidak hanya mengkritisi konsep ketuhanan seperti diyakini umat Kristian, tetapi juga berbeda dari aliran teologi semasanya, sebut saja Asy'ariyah misalnya.

Dasar argumentasi ke-Esa-an Tuhan, lazimnya dikemukakan para teolog, misalnya disandarkan kepada sejumlah ayat yang terdapat di kalam suciNya, Al-Qur'an alKarim. Sebut saja ayat ke-22 sampai dengan 24 dalam Surah ke-59 (alHasr) yang menurut Rahman menyatakan Tuhan sebagai Pencipta (Creator), Pengayom (Maker), Desainer (Fashioner) dengan serangkaian nama-nama indah. Dia Maha Merajai dan Maha Bijaksana. Bahkan Al-Qur'an memandang ketidakpercayaan akan Tuhan, secara formal maupun substansial sebagai immoral (Rahman, 1980). Keterangan lain tentang ke-Esa-an Tuhan, secara jelas terdapat di pangkal Surah ke114 (al-lkhlas).

Menariknya, didapati adanya diferensiasi ungkapan yang terdapat pada satu kata tentangNya (Tuhan), yakni di samping sebagai Pencipta, Dia juga Pengayom dan Desainer alam raya (semesta). Pandangan dimaksud seperti berlaku di kalangan Sunni, bahwa ketika membicarakan prinsip dasar ajaran Islam (tauhid), berhubungan dengan klasifikasi nilai-nilai ketuhanan yang mereka yakini. Ketiganya adalah 'tauhid al-rububiyah', 'tauhid aluluhiah' dan 'tauhid al-asma' wa alsifat. Terma pertama terkait dengan posisiNya sebagai Pencipta dan yang kedua menggambarkan kedudukannya bagi keterbutuhan ciptaanNya; Tuhan adalah
Pengayom semesta. Adapun yang terakhir, pengakuan atas namanama AgungNya (al-asma' al-husna) beserta pemahamannya.

Kembali kepada polemik di atas, Pavlin misalnya dengan baik memetakan persoalan ini dengan mengatakan bahwa Tuhan dan sifatsifatNya menjadi tema utama dari substansi perdebatan yang terjadi. Kontoversi teologis yang mulanya dimotori oleh pendapat kalangan Mu'tazilah dengan menyatakan tidak adanya sifat-sifat Tuhan, disusul bantahan oleh pemuka utama Asy'ariyah, Abu Hasan al-Asy'ari. Jika yang pertama dengan terang menafikan sifat Tuhan, al-Asy-ari bersama pengikutnya (Asy'ariyah) justru mengakuinya sebagai bagian dari ke-tauhid-an. Sebagai kelompok yang menisbatkan diri kepada generasi awal Islam (Salaf), alAsy'ari pun menetapkan adanya sifat bagi Tuhan. Hanya saja, berbeda dari pendahulunya, al-Asy'ari adalah pelopor ta'wil bagi sejumlah ayat mutasyabihat (Nasir, 2010).

Kendati begitu, ta'wil adalah dibatasi dalam persepsi al-Asyari. Hal ini misalnya terlihat dari ungkapannya ketika memberi pemahaman atas kata "istawa" dalam Al-Qur'an (lihat Q.S. al-A'raf [7]:54, Yunus [10]:3, ar-Ra'd [13]:2, al-Furqan [25]:59, as-Sajadah [32]:4, dan al-Hadid [57]:4). Adalah benar baginya bila Tuhan berlaku demikian, tetapi tidak perlu-bahkan terlarang-untuk mempertanyakan bagaimana Dia melakukannya. Prinsip ini dikenal dengan ungkapan 'bila kaifa', sebuah istilah yang digunakan al-Asy'ari ketika dihadapkan dengan dalil-dalil (baca; nash) yang sifatnya zhanni (mutasyabihat). Sebagaimana alAsy'ari, terkait hal ini, al-Maturidi 
juga mengakui adanya sifat-sifat bagi Tuhan (Farida, 2014).

Karenanya,

al-Maturidi

meyakini bahwa Tuhan mengetahui dan berkuasa misalnya, bukan dengan dzat-Nya. Hanya saja, pengetahuan-Nya tidak sebagaimana dipahami dengan "al"ulm" dan kuasa-Nya tidak seperti diartikan dalam terma "al-qudrah" (Mufid, 2013). Kesamaan lain antara al-Maturidi dan al-Asy'ari terlihat ketika dia mengkonfirmasi perdebatan tentang "ke-makhluk-an Al-Qur'an" yang tengah heboh kala itu sebagai akibat dari pernyataan kaum Mu'tazilah. Baginya, kalam Allah tidak diciptakan (makhluk; baharu), tetapi qadim (Nasution, 1986). Adapun dalam soal anthropomorphisme dia cenderung kepada pemahaman Mu'tazilah, bahwa ayat-ayat yang menggambarkan sifat jasmaniah Tuhan mesti diberi arti kiasan (majazi) dengan melakukan interpretasi (ta'wi) (Farida, 2014).

b. Takdir (al-Qada'wa al-Qadr)

Berbeda dari kata sepakatnya dengan al-Asy'ari tentang penetapan sifat bagi Tuhan, al-Maturidi menganggap bahwa manusia mempunyai kebebasan untuk menentukan perbuatannya. Bahkan, mereka adalah sebenar pelaku dalam hal itu (Nasution, 1986). Sebuah keyakinan yang berseberangan dari pola berpikir alAsy'ari.

Pandangan al-Maturidi mengenai hal ini, tentunya berangkat dari pemahamannya mengenai definisi atas al-qada' dan al-qadr di mana yang awal menurutnya dapat diklasifikasikan menjadi empat pengertian. Pertama bahwa al-qada' bermakna al-hukm (menghukum) dan al-qat'u (memutuskan). Namun pada intinya adalah menciptakan (alkhalaqa). Ini didasarkan pada ayat ke-12 Surah al-Fushilat (41). Kedua, al-qada' diartikan dengan al-i'lan (berita) dan al-akhbar (informasi) seperti didapati pada ayat keempat Surah ke-17 (al-Isra'). Kemudian alqadajuga berarti al-'amr atau perintah (Q.S. al-Isra' [17]:23) dan terakhir bermakna al-farqh (selesai, sempurna). Namun yang terakhir tidak berkaitan secara langsung dengan Allah (Q.S. al-Qasas [28]:29).

Berdasarkan keterangan di atas, dapat dikemukakan inti dari pemahaman al-qada' al-Maturidi berkisar seputar ketetapan, hukum dan informasi Tuhan. Adapun alqadr, seperti halnya al-qada', dibaginya ke dalam dua artian. Pertama bahwa ia bermakna ukuran (had) dan juga penjelasan tentang benar dan salah, pahala dan dosa, baik dari segi tempat maupun waktunya (Amin, 2013). Penjelasan ini pula yang misalnya didapati dalam sebuah hadis mengenai Islam, iman dan insan (an-Nawawi, 2010). Karenanya, terkait hal ini, alMaturidi melihat adanya celah untuk menyatakan bebasnya manusia dalam menentukan pilihan bagi perbuatannya. Ruang kebebasan manusia inilah yang agaknya menjadi jembatan penghubung antara ketetapan (al-qadr) Tuhan dan upaya (ikhtiar) manusia.

Sebagaimana diketahui, sehubungan dengan masalah ini, Mu'tazilah dengan tegas menyatakan bila manusia merupakan pelaku utama dari perbuatannya, sementara Asy'ari dan Asy'ariyah-yang lebih dekat pemahamannya dengan Jabariyahmenyebut bahwa manusia hanya dapat berusaha (al-kasb), namun 
tidak mampu merubah ketetapan (takdir) Tuhan. Al-Maturidi dengan konsep mash'iah dan ridha-nya tampak berusaha melerai kontroversi kedua pandangan sebelumnya. Baginya, perbuatan manusia yang baik adalah atas prakarsa ke-ridhaan Tuhan, sedangkan yang buruk tetap dengan kehendak-Nya namun tidak beserta ridha-Nya (Amin, 2013).

Karenanya dalam persepsi alMaturidi, kebebasan manusia adalah kaitannya dengan memilah antara kebaikan atau keburukan dan bukan dalam rangka menciptakan perbuatan itu sendiri (Afrizal, 1998). Pendapat al-Maturidi ini didasarkan pada keyakinan bahwa manusia dengan akalnya mampu menggapai empat dasar pengetahuan yang pernah dikemukakan oleh Mu'tazilah, yakni mengetahui Tuhan, kewajiban untuk mengenal-Nya, mengetahui kebaikan dan keburukan, juga kewajiban melakukan perbuatan baik dan menghindari perbuatan buruk (kejahatan) (Martin, 2003). Berdasarkan hal ini pula, al-Maturidi dianggap telah memberikan perhatian (baca; peran) yang lebih kepada akal jika misalnya dibandingkan al-Asy'ari-kendati tidak se-ekstrem kelompok Mu'tazilah.

Menjadi maklum jika kemudian kedudukan al-Maturidi dalam teologi Islam diletakkan pada posisi pertengahan, berada di antara Asy'ari dan Mu'tazilah. Pilihan bersikap demikian, nyatanya didapati ketika dia merespon sejumlah masalah yang diperdebatkan, mulai dari kebebasan manusia dan sifatsifat Tuhan. Agaknya, konsepsi mash'iah dan ridha al-Maturidi itu berangkat dari pemahamannya tentang tanggung jawab pribadi yang mesti diemban atas kebebasan memilih manusia-sebagaimana telah diberikan Tuhan. Sebuah upaya untuk menjelaskan keterkaitan antara kebebasan manusia dan ke-MahaTahu-an Tuhan dengan tanpa terjebak pada kepasrahan (fatalism) dan untuk selanjutnya dikenal sebagai "deistic approach".

Berdasarkan pemaparan di atas, tampak bagaimana sikap berdiri yang seakan hendak ditawarkan oleh al-Maturidi. Oleh karena tidak ingin semata menyatakan kata setuju atas konsep al-kasb (ikhtiariyyah) seperti diajukan al-Asy'ari, juga tidak pula membenarkan keyakinan Mu'tazilah atas kebebasan penuh manusia (dengan tanpa adanya campur tangan Tuhan) dalam menciptakan perbuatan-perbuatannya. Sebuah prinsip yang kiranya mampu menjembatani antara sekadar pasrah dan berupaya semata tanpa disertai pengakuan (recognition) adanya keterlibatan peran Tuhan di dalamnya.

c. Janji dan Ancaman Tuhan (al Wa'ad wa al-Wa'id)

Berbeda dari Asy'ari, mengenai persoalan ini, al-Maturidi terlihat meng-amin-kan pendapat Mu'tazilah yang meyakini bahwa janji-janji baik dan ancamanancaman Tuhan pasti terjadi kelak (Nasution, 2012). Jika al-Asy'ari menyatakan tidak adanya sesuatupun kewajiban bagi Tuhansebab Dia dipahami sebagai entitas yang berada di atas segalanyamaka al-Maturidi, seperti halnya kalangan Mu'tazilah, mengangap Tuhan memiliki kewajiban-kewajiban tertentu yang mesti dilakukan-Nya. Hanya saja, kewajiban-kewajiban 
Tuhan itu, bagi al-Maturidi, sekedar berkisar pada persoalan balasan atas kebaikan ataupun keburukan yang dilakukan manusia selama berada di dunia (sekarang) ini.

Adapun bagi faksi Mu'tazilah, kewajibanNya meliputi keseluruhan aspek yang berkaitan dengan nilainilai ketuhanan lainnya, seperti wajibnya Tuhan untuk melakukan keadilan dan kewajiban untuk menciptakan apa yang disebut sebagai baik dan terbaik (al-shalah wa al-'ashlah), kewajiban untuk tidak memberi beban di luar kemampuan manusia (taklif ma la yuthlaq), juga wajibnya Dia untuk mengirim utusanNya (rasul) di tengah-tengah manusia. Serangkaian kewajiban dimaksud menurut Abduh, sebagaimana dikatakan Harun, adalah bentuk konsistensi dari adanya kehendak (qudrah) pada Tuhan (Nasution, 2006). Berseberangan dari kedua pandangan sebelumnya (Mu'tazilah dan al-Maturidi), al-Asy'ari tidak sedikitpun memberi ruang bagi adanya kewajiban-kewajiban Tuhan.

d. Iman

Berbagai persoalan yang dibahas dalam tulisan ini, menampilkan tidak sedikitnya perbedaan pandangan di antara kelompok-kelompok keagamaan (firqah) di tubuh umat Islam, tidak terkecuali halnya dalam soal iman. Harun misalnya membagi hal tersebut ke dalam dua kategori, yakni iman yang didasarkan pada keyakinan (tashdiq) dan iman berlandaskan akal atau pikiran (ma'rifah). Perbedaan keduanya terletak di ranah episteme-nya. Jika yang pertama membenarkan atas apa yang diberitakan (wahyu), sementara yang kedua meyakini berdasarkan upaya pada pengetahuan mendalam (Amin, 2013). (rasionalisasi pemikiran).

Pandangan al-Maturidi tentang masalah ini, sekiranya mirip dengan persepsi Mu'tazilah dan berseberangan dengan pendapat alAsy'ari yang menyatakan bahwa mengenal Tuhan tidak sedikitpun dapat dicapai melalui akal (pikiran, rasio). Sekalipun tidak juga sepenuhnya sama dengan kalangan Mu'tazilah dengan anggapan bahwa pelaku dosa besar tidak mukmin dan tidak pula kafir yang untuk kemudian dinyatakan lewat ungkapan 'almanzilah baina al-manzilatain', baik Maturidiyah Samarkand maupun Bukhara sepakat untuk tidak memberikan gelar "kafir" kepadanya. Sedangkan pendapat al-Maturidi sendiri, mengenai iman, cenderung mengarah kepada defenisi ma'rifah-seperti termuat dalam Syarh al-Fiqh al-Akbar-di mana manusia mengetahui Tuhan dalam ketuhanan-Nya (Nasution, 2006).

Lebih jauh, Harun juga menyatakan jika ma'rifah seperti terdapat pada pendapat al-Maturidi adalah mengetahui Tuhan dengan segala sifat-Nya, sementara tauhid bermakna mengetahui Tuhan dalam ke-Esa-an-Nya (Nasution, 2006). Berangkat dari definisi ini, dapat dipahami bila pemikiran al-Maturidi tentang iman begitu berkait berkelindan dengan keyakinannya atas prinsip tauhid. Konsekuensi logisnya, keimanan senantiasa berjalan sekaligus berdiri di atas fondasi satunya (ketauhidan) Tuhan. Adapun dalil al-Maturidi untuk menyatakan bahwa pelaku dosa besar-dalam perbuatan terburuk sekalipun-sebagai tidak kafir, didasarkan pada sikap penyerahan diri kepada putusan Tuhan sendiri (irja') (Leaman, 2008). Sebuah 
pilihan sikap untuk tidak menjadi hakim atas perbuatan sesamanya.

Pendapat al-Maturidi di atas, adalah sejalan dengan defini iman yang disebutnya sebagai "Kalbin tasdikinden ibarettir" (Ahmet, 2008) atau "tashdiq bi al-qalb", sebuah pembenaran yang menjadi kerja bagi hati. Menjadi jelaslah kiranya bahwa iman dalam pandangan alMaturidi tidak sama sekali dipengaruhi oleh perbuatan yang dilakukan dan karenanya, segala bentuk perbuatan jahat (dosa) selain syirik berada di luar domain kekufuran. Karenanya, dia meyakini bahwa seorang Muslim tidak dapat dikatakan murtad hanya karena tidak melaksanakan ibadah wajib maupun dosa besar lainnya, selama dia masih mengimani Allah (Akimkhanov , 2016)

e. Teologi Politik

Al-Maturidi meyakini hanya ada satu pengetahuan yang disebutnya dengan 'pengetahuan agama'. Karenanya, menjadi dapat dipahami jika pandangan dunia (worldview) nya menjadikan agama sebagai satu-satunya pedoman (guidance) bagi keseluruhan aspek hidup dan kehidupan manusia. Agama baginya tidak hanya membincangkan hubungan antara manusia dan Tuhan (vertical contact), tetapi meliputi ragam persoalan hidup yang dihadapi termasuk di dalamnya mengenai sosial-politik dan moral-etik (horizontal contact) (Masturin, 2014).

Bahasan Islam dan politik sejatinya menjadi di antara tema utama pemikiran teolog (Mutakallimin). Ini dapat dibuktikan bahwa dalam sejarahnya, masalahmasalah yang terdapat di ranah teologi Islam (ilmu kalam), justru bermula dari sebuah pertentangan politik. Bahkan, Syafii Maarif menyebut jika kharakteristik agama Islam di masa-masa awal justru ditandai dengan kejayaannya di bidang ini (Ma'arif, 1985). Agaknya, seperti telah dinyatakan di depan, pandangan al-Maturidi akan hal ini didasarkan pada pemahaman atasdengan meminjam istilah Abdurrahman Wahid-universalisme Islam dan kosmopolitanisme peradaban Islam. Sebuah keyakinan bahwa Islam meliputi berbagai bidang; figh, tauhid dan akhlak yang menampilkan kepedulian besar terhadap kemanusiaan (alInsaniyyah) (Wahid, 2007).

Kuatnya patri keyakinan akan nilai-nilai universal Islam itulah yang pada gilirannya membawa sebagian dari mereka (umat Islam) meyakini bahwa dalam hal politik pun, Tuhan mesti untuk senantiasa dihadirkan (omnipresent). Perbedaan hanya terletak di wilayah pemaknaan, antara legal eksklusif dan substansi inklusif di mana yang pertama memahami bahwa Islam mesti dibumikan-yang dalam konteks kenegaraan-sebagai landasan (fondasi) bagi berdirinya sebuah negara. Adapun yang kedua, memandang bahwa kehadiran Islam di sana adalah lebih dalam wujud substansi (nilai) ajarannya dan menjadi semacam "tameng" bagi roda pemerintahan yang dijalankan. Ringkasnya, Islam adalah "ruh" dan bukan tubuh.

Tampaknya, al-Maturidi cenderung menyetujui pandangan terakhir itu di mana menurutnya tidak ada satupun dalil yang mengarah pada apa yang dinyatakan sebagai 'kewajiban suci' bagi sebuah pola kepemimpinan. Baginya, ketika Nabi Muhammad s.a.w., diangkat menjadi pemimpin 
Negara Madinah, adalah tidak dalam rangka didasarkan pada kenyataan bahwa ia utusan Tuhan (rasul), melainkan disebabkan pengakuan mereka atas kapasitas leader yang ada pada dirinya. Kenyataan ini semakin memperkuat fakta bahwa persoalan dimaksud dalam perspektif al-Maturidi hanyalah berada di ranah ijtihadiyah dan bukan keyakinan (aqidah). Baginya al-naskh al-ijtihadi adalah sebuah instrumen yang dapat dijadikan dasar bagi kehidupan per-politik-an dewasa ini (Wojcik, 2010)

\section{PEMIKIRAN AL-MATURIDI TENTANG KEADILAN TUHAN}

Sebagai murid sekaligus pengikut Abu Hanifah, al-Maturidi terlihat menampilkan sikap mengedepankan rasionalitas dalam memberikan penjelasan tentang keadilan Tuhan. Sekalipun demikian, hal itu tidak lantas diiringi dengan pilihan untuk sekadar menjadikan AlQur'an sarana "konfirmasi" pemikirannya sebagaimana dilakukan oleh kelompok Mu'tazilah. Dia tidak juga seperti al-Asy'ari yang cenderung memahami nash apa adanya (baca; tekstualis). Pada wilayah bahasan ini, dapat dikatakan bahwa ia semacam berupaya memadukan (sintesis) antara dalil keagamaan dan logika atau dengan lain kata, membaca teks berdasarkan konteksnya secara bersamaan.

Menurut Harun Nasution, pemikiran tentang keadilan Tuhan memiliki banyak keterkaitan dengan kebebasan manusia ataupun sebaliknya, kekuasaan mutlak Tuhan (Nasution, 1986). Karenanya, secara teologis, pembicaraan mengenai hal ini senantiasa berorientasi kepada dua arus utama pemikiran kalam, Jabariyah dan Qadariyah yang secara esensi direpresentasikan oleh paham keagamaan (firqah) Mu'tazilah dan Ahl al-Sunnah wa al-Jama'ah (alAsy'ariyah dan al-Maturidiyah). Hal menarik atas kenyataan demikian, seperti diungkapkan Machasin (Machasin, 1996), bahwa mereka sama-sama menjadikan ayat-ayat Al-Qur'an (dalam berbagai variannya) sebagai dasar argumentasi (dalil) bagi persepsi yang diimani (i'tiqad).

Demikian halnya dengan konsepsi al-Maturidi atas persoalan ini. Pandangan-pandangannya tentang keadilan Tuhan tentunya tidak juga dapat dilepaskan dari pemahamannya akan status perbuatan manusia, seperti telah dipaparkan di atas. Sebagai sebuah konsep pemikiran, penjelasan alMaturidi mengenai masalah dimaksud, akan dijelaskan lebih dalam pada kerangka pemikiran berikut.

\section{Tuhan Yang Maha Adil (al-'AdI)}

Tidak diragukan lagi bahwa hampir keseluruhan bahkan semua umat Islam meyakini Tuhan sebagai Maha Sempurna, Maha Pengasih dan Penyayang, juga Maha Adil. Sekalipun antara al-Asy'ariyah dan Mu'tazilah misalnya seringkali berada pada titik persinggungan (perdebatan), namun dalam hal ini mereka-juga aliran-aliran keagamaan Islam (firqah) lainnyameyakini bahwa Tuhan Maha Adil. Perbedaan keduanya (Sunni dan Mu'tazilah) hanya terletak pada sudut pandang yang digunakan dalam meneropong soal keadilan. Jika yang pertama mendasarkan argumentasinya pada kekuasaan dan kehendak mutlak Tuhan, 
sementara yang terakhir mendirikan pendapatnya di atas prinsip kebebasan sebagaimana telah diberikan Tuhan kepada manusia (Dahlan, 2012).

Sekalipun tidak sepandangan dengan penafsiran al-Asy'ari tentang sifat-sifat Tuhan, namun pada esensinya al-Maturidi tetap mengakui adanya keberadaan halhal demikian bagi-Nya. Al-Adl sebagai satu di antara 99 nama (alasma' al-husna) yang disematkan kepada Tuhan, karenanya dalam keyakinan al-Maturidi menjadi di antara karakteristik yang tidak boleh tidak ada pada Tuhan. Dia mesti ada pada eksistensi-Nya. Oleh sebab itu, konsepsi keadilan Tuhan al-Maturidi didasarkan atas keyakinan bahwa Tuhan adalah adil dan karenanya menjadi mustahil bagi-Nya untuk melakukan apa yang dikenal dengan sebutan ketidak-adilan (zalim).

Tidak sedikitnya Sabda Tuhan yang menghendaki manusia bersikap demikian (adil), menjadi di antara indikator utama bahwa Dia mestilah Yang Maha Adil. Bahkan, Wahid menyebut jika salah satu ketentuan dasar yang dibawa Islam adalah keadilan (Wahid, 2006). Karenanya, merupakan sebuah ketidak-logisan bila penyeru bagi tindakan-tindakan keadilan justru berlaku sebaliknya, tidak adil. Hanya saja, apa yang perlu digarisbawahi di sini bahwa nilai adil dalam pikiran al-Maturidi tampak diposisikan di antara kehendak mutlak Tuhan (alAsy'ari) dan kebebasan penuh manusia (Mu'tazilah), selain memang paradigma berpikirnya tentang iman didirikan di atas pembuktian logis (logical proofs) berdasarkan pengaruh gurunya, Abu Hanifah (Akimkhanov, 2016).
Sebagaimana diketahui, Abu Hanifah merupakan sosok ahli fiqh yang menurut Hasbi Ash Shiddieqy memiliki kecerdasan pikiran di atas rata-rata dan kenyataan ini pula yang tidak sedikit mengundang kedengkian orang terhadapnya di mana kebanyakan dari mereka tidak dapat menandingi pendapatnya. Dia juga adalah pribadi yang berani keluar dari "zona nyaman" pemikiran, seperti menerima apa yang dikatakan tokoh semasanya sebagai bid'ah, bahkan menjadikan urf (tradisi) sebagai suatu dasar hukum di mana pada saat bersamaan tidak jarang menggunakan ra'y (rasio) dalam meng-instinbat-kan suatu perkara (Hasbi, 1997).

Sekali lagi, bukan tidak pada tempatnya jika pemikiran Abu Hanifah begitu mewarnai pandangan-pandangan keagamaan al-Maturidi. Prinsip logical proofs yang digunakannya baik ketika membincangkan keberadaan dan wajibnya eksistensi bagi Tuhan (wajib al-wujud), ketauhidan serta bagaimana ia menjelaskan kesemuanya itu jelas mencerminkan ketertarikannya yang besar kepada dunia logika. Oleh sebab itu, tidak pula dapat diingkari bahwa alMaturidi kelihatannya sepakat dengan para ahli filsafat (filsuf) atas pentignya keabsahan sebuah argumentasi dalam mempertahankan apa yang dinyatakan sebagai kebenaran (Ponjam, 2001). Adapun ditinjau dari keterangan Harun dan Machasin di depan di mana masalah keadilan Tuhan erat kaitannya dengan status perbuatan manusia. Hal ini tentunya juga memiliki "benang merah" terhadap balasan atas kebaikan dan 
keburukan yang telah dilakukan manusia selama berada di dunia, oleh Tuhan. Meskipun begitu, lazimnya diketahui bahwa yang pertama (balasan kebaikan) bukan menjadi suatu perkara yang dipersoalkan. Tidak demikian halnya dengan yang kedua, balasan atas kejahatan dan perbuatan buruk manusia mengundang perdebatan di antara teolog Muslim, tidak terkecuali Mu'tazilah dan Asy'ariyah.

\begin{tabular}{lr}
\multicolumn{2}{c}{ Penolakan al-Maturidi } \\
terhadap konsep
\end{tabular}
pertengahan" (al-manzilah baina almanzilatain) antara Mukmin dan Kafir bagi pelaku dosa besar seperti disuarakan Mu'tazilah, juga tidak secara eksplisitnya ia dalam mengamin-kan pandangan al-Asy'ariyah sehubungan dengan masalah ini, nyatanya memunculkan pendapat tersendiri al-Maturidi dan sekiranya tampak berada di antara argumentasi keduanya. Agaknya terkait hal ini, ia lebih condong kepada pendapat kaum Murji'ah dengan mengedepankan sikap arja (memberi harapan adanya kema'afan Tuhan). Asumsi ini didasarkan pada pernyataannya bahwa soal dosa besar seseorang biarlah menjadi urusan Tuhan, begitu pula halnya dengan balasan siksanya (Nasir, 2005)

Sesuai dengan pandangan tersebut, utamanya sehubungan dengan konsep iman, tampak bahwa hal ini menurutnya merupakan pilar utama keberagamaan setiap Muslim. Iman tidak saja sebagai prasyarat terdepan bagi nilai keselamatan (salvation) manusia di dunia ini dan kehidupan di kemudian hari (akhirat), tetapi sekaligus menjadi kata kunci (key word) bagi kemungkinan diringankannya balasan (baca; siksa) atas keburukan yang diperbuat. Pada konteks ini, al-Maturidi seolah ingin menunjukkan bahwa Tuhan Yang Maha Adil, juga perlu alasan pertimbangan untuk menghadirkan sikap kebijaksanaan-Nya. Selain memang merujukkan pendapatnya kepada dalil agama (nash), penjelasannya akan hal ini sarat dengan muatan rasionalitas.

Argumentasi yang dibangun alMaturidi di atas, tampaknya berupaya mengingatkan manusia akan kausalitas (konsep sebabakibat). Artinya, sekali lagi, sikap bijaksana dan adil bagi Tuhanseperti tercemin dari keyakinan alMaturidi-berdiri di atas nilai-nilai pertimbangan. Oleh karena adanya iman itulah, Tuhan dimungkinkan meringankan balasan atas perbuatan buruk manusia. Adapun tidak dimasukkannya perbuatan dosa selain syirik sebagai kesalahan yang tidak terampuni, adalah bermuara pada keyakinan alMaturidi tentang kebenaran AlQur'an. Pada saat bersamaan, berbedanya balasan kejahatan (siksa) di antara Mukmin dan kafir yang dikemukakan al-Maturidi, adalah dalam rangka menyatakan bahwa Tuhan tidak mungkin tidak mempertimbangkan keberadaan iman sebagai kebaikan terbesar manusia (Zar, 2014).

\section{Tuhan Yang Maha Bijaksana (al- Hakim)}

Selain menurunkan wahyuyang dalam teori pengetahuan (knowledge) al-Maturidi disebut sam' (tradisi, nash)_kepada manusia, Tuhan juga telah membekali mereka dengan akal (aql, reason). Upaya alMaturidi dalam mempertautkan keduanya itulah membuatnya disebut sebagai teolog Muslim pertama yang memberikan perhatian 
lebih kepada teorisasi pengetahuan (Basaran, 2011). Kata sam' yang dinyatakan al-Maturidi dapat diartikulasikan sebagai pendengaran, sedangkan pengetahuan sam' bermakna prinsip umum dari pengetahuan tradisional yang diperoleh seseorang melalui berita, bukan dengan indera atau akal (Masturin, 2014).

Pun begitu halnya dengan akal, sebagai sebuah anugerah terbesar dari Tuhan kepada mahkluknya, sekaligus diferensiasi antara manusia dan jenis (species) hewan lainnya-seperti adagium terkemuka "al-insan hayawan alnathiq"-di mana akal merupakan sarana bagi manusia untuk memahami apa yang diberitakan (diwahyukan) kepadanya. Adapun keterkaitan antara konsepsi pengetahuan al-Maturidi dengan masalah keadilan Tuhan adalah bahwa pengetahuan yang diperoleh manusia menjadi semacam keyakinan; sebuah pendapat yang kuat (conviction) akan mengarahkan kepada apa yang disebut meng-iyakan (assent) (Ramazan , 2011). Secara definitif, keterangan dimaksud mendukung tesis bahwa dengan kemampuan berpikirnyalah manusia dapat memilah atas pilihan (jalan) yang telah disediakan Tuhan (Q.S. al-Balad [90]:10).

Berdasarkan pengertian itu, pengetahuan tertinggi akan Tuhan (ma'rifah) dalam pandangan alMaturidi adalah didasarkan pada pemikiran dan akal manusia (Nasir, 2005). Informasi ini sekaligus memberi bukti bahwa akal manusia, sebagaimana diyakini al-Maturidi, sanggup memahami apa yang juga menjadi di antara objek terpenting ajaran para sufi (ma'rifah), selain memang merupakan bahasan utama di kalangan Mu'tazilah. Namun demikian, sebagaimana dikemukakan Nasir, hal itu tidak lantas membuat al-Maturidi dengan tanpa ada batas pemisah signifikan dengan firqah Mu'tazilah. Bahkan, tidak pula karena itu dapat memasukkannya ke dalam bagian kelompok keagamaan dimaksud.

Penjelasan di atas sejalan dengan pendapat al-Maturidi yang menyatakan bahwa manusia tidak dapat memperoleh pengetahuan tentang Tuhan melalui indera dan informasi (khabar) di mana pengetahuan tentang-Nya dapat diperoleh melalui dunia sebagai bukti akan keberadaan (eksistensi) Nya. Artinya, indikasi yang diketahui (shahada) untuk yang tidak diketahui (ghayb) (Erdem, 2007). Berangkat dari definisi ini, terlihat bahwa makna keadilan Tuhan yang termuat dalam pemikiran al-Maturidi adalah dengan seiringnya pemberian akan petunjuk (wahyu) dengan sarana untuk memahaminya (akal). Pandangan ini sekaligus menghendaki pengakuan atas kebijaksanaan Tuhan.

Wujud dari keyakinan akan sikap bijaksana Tuhan dan perlakuan adil yang akan diterima manusia adalah dengan membaca wahyu dengan akal sebagai jalan melahirkan pengetahuan (knowledge) bagi manusia, seperti dimaksud oleh al-Maturidi. Karenanya ayat-ayat kauniah yang secara universal terhimpun dalam ungkapan "di langit dan di bumi", proses penciptaannya, pergantian siang dan malam, serta segala potensinya yang bernilai guna (bermanfaat) untuk manusia (Q.S. al-Baqarah [2]:164) menjadi objek renungan (akal) nya. Dorongan berbuat demikian itulah yang dipahaminya sebagai kemerdekaan 
berkehendak (mashi'ah)-yang

menghindari segala bentuk

keburukan dan sangsinya (Q.S. alMulk [67]:10).

Jalan untuk mencapai keselamatan itu dalam konsepsi alMaturidi adalah dengan tidak mengabaikan segala bentuk potensi yang ada pada diri, seperti kemampuan memahami dengan hati, kesanggupan untuk memperhatikan lewat mata dan telinga di mana keseluruhan kehendak demikian adalah demi menghindari penyesalan di hari kemudian sebagaimana diperingatkan Tuhan (Q.S. al-A'raf [7]:179). Pada ranah inilah agaknya, posisi akal manusia oleh al-Maturidi diletakkan, yakni sebagai pengambil nilai peringatan (i'tibar). Pada saat yang sama, pentingnya pengetahuan bagi manusia menurutnya agaknya didasarkan pada keterangan bahwa kesungguhan mencapai hal itu pun menjadi sarana manusia menuju Tuhan (Q.S. al-Insyiqaq [84]:6) dan dimuliakan (Q.S. al-Mujadalah [58]:11).

Konsepsi keadilan Tuhan dalam pandangan al-Maturidi di sini, terkait kearifan Tuhan, tidak lain merupakan sebuah upaya memaknai antara seruan berbuat kebaikan dan kemampuan manusia dalam memahami kebaikan itu sendiri. Agaknya dalam hal ini, pendapatnya sejalan dengan apa yang juga pernah disampaikan oleh filsuf terkemuka awal Yunani, Socrates (470-399.SM) di mana ia menyatakan bahwa perbuatan jahat adalah sebagai akibat ketidaktahuan manusia akan kebaikan. Apabila seseorang dengan budi (akal) nya adalah tahu, maka tidak ada di antara mereka yang sengaja atau berdasarkan kemauannya sendiri untuk melakukan kejahatan (Hatta, 2006)

Diakuinya ketunggalan pengetahuan manusia yakni "pengetahuan keagamaan" oleh alMaturidi itulah agaknya, menjadi sebentuk petunjuk bagi manusia dalam mencapai konsep keselamatan atas hidup dan kehidupannya. Agama karenanya merupakan satu-satunya sumber pengetahuan bagi manusia yang tidak hanya mengatur hubungan antara dia dengan Tuhan, tetapi juga terhadap sesamanya. Pandangan alMaturidi ini memberi kesan tidak adanya pemisahan (dikotomi) antara pengetahuan nan llahi dengan yang non Ilahi sebagaimana dapat disaksikan dewasa ini (Masturin, 2014).

Terlihat bagaimana ia sangat menjunjung tinggi upaya manusia untuk melepaskan diri dari belenggu taqlid dengan jalan mendayagunakan semaksimal mungkin segala potensi yang ada di dirinya. Bahkan, sikap melakukan sebuah tindak dengan tanpa didasarkan pengetahuan itu, membuta-tuli (taqlid) baginya tidak akan membawa manusia kepada apa yang disebut sebagai "kebenaran agama tertinggi". Namun begitu, al-Maturidi menjelaskan bahwa tidak mungkin pernyataanpernyataan agama mesti dipahami dengan cara yang sama oleh siapapun (Ramazan, 2011). Pada konteks ini, tampak adanya sebentuk keyakinan bahwa Tuhan akan bersikap atas perbedaan kemampuan hamba-Nya dalam beragama.

Berdasarkan pemaparan sebelumnya, dapat dipahami pula 
bila kebijaksanaan Tuhan dalam pemikiran al-Maturidi memberi satu pengertian mengenai ketidakmungkinan Tuhan berlaku sewenang-wenang. Sekalipun Dia memiliki kekuasaan (qudrah) dan kehendak (iradah) yang mutlak, hal itu tidak lantas membuat-Nya bertindak dengan semena-mena (Nasir, 1960) Tidak setujunya dia dengan pendapat Mu'tazilah yang memberi beban kewajiban bagi Tuhan layaknya Dia memberi kewajiban bagi hamba-Nya, juga tidak sejalannya al-Maturidi dengan al-Asy'ari dengan menganggap Tuhan terbebas sepenuhnya dari kewajiban sebab Dia berada di atas semua hukum dan ketentuan, alMaturidi memaknai kebijaksanaan Tuhan (Syukur, 2006) adalah selarasnya antara keputusan dengan janji-janji dan ancaman-Nya.

\section{Perbuatan Manusia: Kebebasan dalam Keterikatan}

Berdasarkan keterangan terdahulu, diketahui bahwa keyakinan akan Tuhan Yang Maha Adil dalam pandangan al-Maturidi berisikan pemahaman terhadap nilai-nilai kebijaksanaan-Nya. Sikap bijaksana Tuhan itulah yang dalam diskursus kalam (teologi Islam) berkait berkelindan dengan pandangan manusia atas keadilanNya, sekarang dan di masa akan datang.

Al-Maturidi menyatakan dengan tegas bahwa pemikiran tentang kebebasan manusia didasarkan pada argumentasi rasional dan Qur'ani di mana menurut dalil pertama setiap orang merasa bahwa dia bebas dan dapat melakukan apapun dengan tanpa adanya kemauan dari luar yang memaksanya. Pada konteks ini, manusia dengan kesadarannya berbuat sesuatu (tindakan) berdasarkan kesadaran dan bukan keterpaksaan. Selanjutnya, hubungan antara manusia dan Tuhan berbeda dari hubungan antara Tuhan dan benda-benda fisik lainnya (Omar, 1974). Upaya menerjemahkan ikatan keduanya itulah yang melahirkan konsep emanasi di dalam filsafat Islam.

$$
\text { Menurut al-Maturidi, }
$$
sebagaimana dikatakan Kemal Isik, manusia memiliki kehendak nyata pada tindakannya. Manusia menyadari fakta bahwa di setiap saat dan di dalam jiwa mereka, mereka dilibatkan dalam pekerjaannya dan menyaksikan apa yang telah diperoleh dari tindakan itu. Pemahaman demikian dikarenakan Tuhan dengan jelas telah menyatakan para hamba-Nya memiliki kesempatan untuk berbuat dan mengambil tindakannya sendiri (Q.S. Fushilat [41]:40; al-Hajj [22]:77; al-Zalzalah [99]:7-8) (Isik,1980). Kesadaran jiwa dengan kemampuan membedakan baik dan buruk itulah yang dalam pandangan al-Farabi memberi dorongan terlahirnya usaha, membangun seni dan sains (Boer, 1967).

Kebebasan dimaksud adalah pilihan yang walau bagaimanapun tidak berarti menafikan peranan Tuhan di sana dan bahwa setiap tindakan sebagai murni perbuatan manusia. Sebaliknya, manusia tidak dapat melakukan tindakan apapun tanpa Tuhan terlibat di dalamnya. Artinya, sekalipun perbuatan manusia dilakukan dengan kemauannya sendiri, namun tindakan itu dimaksud adalah diciptakan oleh Tuhan (Omar, 1974). Secara leterlek (tektualis), pendapat al-Maturidi ini tampak ambigu sebab Tuhan dan manusia sama-sama 
dianggap sebagai "pencipta" bagi perbuatan yang ada. Namun demikian, sesungguhnya yang ingin disampaikan olehnya bahwa keduanya memiliki peran signifikan bagi terwujudnya tindakan secara bersamaan.

Penjelasan al-Maturidi itu sekaligus menunjukkan sikapnya yang berupaya melerai ekstremisme Mu'tazilah dan pihak Asy'ariyah dalam masalah ini. Jika kelompok pertama dengan tidak mengakui adanya peranan Tuhan sedikitpun pada perbuatan manusia, sementara faksi kedua menyatakan bahwa manusia hanya menjalani takdir sebagaimana telah digariskan oleh Tuhan, maka al-Maturidi menjadikan kesepaduan tindakan manusia dan ridha Tuhan sebagai alternatif demi sebuah usaha untuk tidak mengesampingkan peranan salah satunya. Sikap demikian itu dalam pikiran al-Maturidi dikenal dengan kemauan manusia untuk menggunakan daya (masyi'ah) yang diberikan Tuhan.

Baginya, Tuhan memberinya kapasitas, daya, kemampuan (istita'a) yang oleh al-Maturidi dibagi kepada dua arti, yaitu kapasitas yang memungkinkan (al-qudra almumakkina) dan memfasilitasi kapasitas (al-qudra al-muyassira). Pengertian pertama sifatnya mendahului tindakan, sedangkan yang kedua berjalan bersamaan dengan perbuatan. kapasitas yang memungkinkan tindakan itu seperti adanya tangan, mata, telinga, kaki dan lain semisalnya. Contohnya, bahwa kewajiban untuk menunaikan ibadah haji dapat dilakukan dengan kecukupan sarana di mana kewajiban itu diserukan (Q.S. Ali Imran [3]:97) (Omar, 1974).
Adapun arti "daya" kedua
adalah sesuatu yang sifatnya
temporal (al-qudra al-haditsa). Kapasitas semacam ini menurutnya adalah tambahan untuk yang pertama. "Ketika manusia memiliki niat untuk melakukan sebuah tindakan, Tuhan memberinya kemampuan untuk dapat melakukannya" (Omar, 1974). Pembagian daya dimaksud, jika diperhatikan secara seksama, didapati adanya kemiripan dengan penjelasan al-Farabi (870-950.M) tentang potensi dan aktualitas (Seed, 1962). Oleh sebab itu, diberikannya tangan, akal dan hati oleh Tuhan misalnya, dapat dipahami sebagai potensi yang dikembalikan kepada manusia pemanfaatannya. Pilihan untuk mengerjakan kebaikan atau melakukan kejahatan-dengan sarana-sarana itu-adalah wujud dari apa yang oleh al-Maturidi disebut masyi'ah.

Namun demikian, sebagai makhluk dengan dualitas unsur keberadaan (jasmani dan ruhani), mesti diakui adanya konsekuensi logis bagi manusia atas kenyataan ini. Jika ditinjau dari sisi ruhaniahnya, benar bahwa ia mempunyai kemungkinankemungkinan yang secara relatif tidak terbatas. Akan tetapi, oleh karena ruh itu terbungkus materi (tubuh)-yang memungkinkannya menjadi berada (eksis)—maka menjadi terbataslah ia dari segi ruang dan waktu (Machasin , 1996). Apa yang perlu dipahami di sini bahwa keterbatasan dimaksud tidak sama sekali sebagai bentuk "kesewenang-wenangan" Tuhan dengan kekuasaan-Nya, tetapi lebih kepada sebuah fakta yang mesti diinsyafi manusia. 
Hanya saja, berkat
kebijaksanaan-Nya lah Tuhan mempersilahkan kepada manusia untuk mengucapkan pengharapan (baca; do'a) di mana bagi mereka yang beriman secara benar (tauhid) kepada-Nya, diberikan legitimasi (jaminan) bagi dikabulkannya segala permintaan yang disertai dengan tata krama (etika), ketulusan dan harapan serta berpikir positif atas segala keputusan-Nya (Q.S. al-A'raf [7]:55-56; al-Baqarah [2]:186; alMu'minun [23]:60). Ruang ini dalam terminologi Islam disebut sebagai syari'at; sebuah formulasi doktrinal berisi tata aturan yang meliputi berbagai bidang kehidupan (Lazar, 2015). Beriringnya antara kehendak manusia dengan keridhaan-Nya itulah yang dimaksudkan al-Maturidi sebagai al-qudra al-haditsa (daya temporal) (Isik, 1980).

Kapasitas manusia yang dimaksudkan al-Maturidi pada penjelasan di atas, terlihat sejalan dengan pengertian manusia sebagai wakil, penguasa, pemimpin dan pengelola bumi atau dinyatakan Tuhan dengan terma "khalifah" (Q.S. al-Baqarah [2]:30; al-Fathir [35]:39; al-An'am [6]:165). Dia diciptakan dalam bentuk sebaik-baiknya (Q.S. at-Tin [95]:5), juga dimuliakan (Q.S. al-Isra' [17]:70) dengan tugas mewujudkan kemakmuran (Q.S. Hud [11]:61) dan kebahagiaan serta keselamatan bagi kehidupan di bumi (Q.S. al-Ma'idah [5]:16) melalui iman dan amal salehnya (Q.S. al-Ra'd [13]:29) yang disertai kesabaran dan kebenaran (Q.S. al-'Asr [103]:3). Serangkaian keterangan ini semakin memperkuat kenyataan bahwa manusia tidak dapat mengabaikan kodratnya sebagai ciptaan.

Selanjutnya, dijadikannya manusia sebagai khalifah Tuhan bersamaan dengan dibekalinya mereka kemampuan yang dalam bahasa al-Maturidi disebut al-qudra al-mumakkina dan al-qudra almuyassira (al-qudra al-haditsa) untuk kemudian melahirkan apa yang dinamakan "kreativitas", membenarkan pembacaan atas AlQur'an bahwa manusia adalah subjek kebudayaan (Asy'arie, 1992). Kebudayaan yang juga diartikan sebagai hasil cipta, karya dan karsa manusia, menyiratkan informasi jika mereka merupakan "pencipta" dalam arti temporal. Oleh karena kesadaran akan ketersituasian keberadaan sebagai hamba, maka segala bentuk perbuatan dimaksud tidak lain dalam rangka realisasi kepatuhannya kepada Sang Pencipta (Tuhan).

Kebebasan dalam Islam dapat dipahami ibarat gerakan menunjang oleh seekor kuda yang diikat dengan tali: Laksana otoritas yang menyiratkan tanggung jawab serta akuntabilitas dan memberikan pembenaran untuk hari penghakiman. Oleh karenanya dari perspektif Islam tidak ada kebebasan tanpa keadilan di mana keduanya telah menjadi inspirasi dan motivasi bagi revolusi besar di dunia, baik di ranah politik, sosial, maupun ekonomi (Madani, 2011)

\section{KESIMPULAN}

Konsep keadilan Tuhan alMaturidi didasarkan pada keyakinan bahwa Tuhan Maha Adil dan Maha Bijaksana yang dapat dibuktikan lewat alam semesta. Keadilan-Nya menurut al-Maturidi, adalah dengan tidak dimonopolinya perbuatan di mana Dia memberi kebebasan berkehendak (masyi'ah) kepada manusia dalam menentukan pilihan atas perbuatannya. Adanya ruang 
memilih inilah yang menjadikan wajar jika manusia dikenai pertanggungjawaban: Sebuah penilaian atas penggunaan daya (istita'a) Tuhan pada dirinya. Sekalipun demikian, kebebasan dimaksud bukan tanpa batasan. Manusia pada kodratnya tetaplah memiliki keterbutuhan akan Tuhan yang disebabkan keterbatasan kemampuannya. Kenyataan ini dalam konsepsi Islam disebut sebagai kesadaran ketersituasian manusia sebagai ciptaan dan khalifah-Nya (hamba). Oleh karena Tuhan Maha Bijaksana, maka balasan atas kebaikan mestilah berbeda ukurannya dari balasan atas dosa. Pahala boleh dilipatgandakan, tetapi tidak pada hukuman (siksa). Pada konteks ini, al-Maturidi juga meyakini jika Tuhan tidak akan menyamakan siksaan yang akan diterima orang beriman (Mukmin) dengan mereka yang ingkar (Kafir) sekalipun sama-sama berdosa. Akhirnya, konsep keadilan Tuhan al-Maturidi dimaksudkan untuk sebentuk pengajaran terhadap manusia agar tidak menjadi hakim bagi tindakan dan perbuatan sesamanya.

\section{DAFTAR PUSTAKA}

Abbas, Sirajuddin, 1994. I'tiqad Ahlussunnah Wal-Jama'ah, Kelantan: Pustaka Aman Press Sdn. Bhd.

'Abd Fattah al-Maghribi,. 1985. 'Ali, Imam Ahlu al-Sunnah wa alJama'ah 'Abu Mansur alMaturidi wa 'Ara'uhu alKalamiyah, Kaherah: Maktabah al-Wahbah.

Abdel Haleem, M. 2003., "Kalam Awal", dalam S. H. Nasr dan Oliver Leaman (eds.), Ensiklopedi Tematis Filsafat
Islam: Buku Pertama, terj. Tim Penerjemah Mizan, Bandung: Mizan.

'Abd-Allah al-Omar, Farouq 'Omar. 1974. The Doctrines of Maturidite School with Special Reference to As-Sawad alA'zam of Al-Hakim AsSamarqandi, Edinburgh: P.hD Thesis in The University of Edinburgh.

Afrizal M. 1998. Ibn Rusyd dan Pemikiran Kalamnya, Pekanbaru: Susqa Press.

Ahmet AK. 2008. Maturidi ve Maturidilik, Istanbul: Buyuk Turk Alimi.

Akimkhanov, Askar Bolatbekovich, dkk,. 2016. "Principles of Abu Mansur al-Maturidi, Central Asian Islamic Theologian Preoccupied with the Question of the Relation between the Iman/Credo and the Action in Islam", European Journal of Science and Theology, vol. 12, no. 6.

Amin, Saidul. 2013. Pembaharuan Pemikiran Harun Nasution dan Sumbangannya di Indonesia, Kuala Lumpur: Thesis Ph.D University Malaya.

Armstrong, Karen. 2002. Islam: A Short History, New York: Modern Library Paperback Edition.

Asy'arie, Musa. 1992. Manusia Pembentuk Kebudayaan dalam Al-Quran, Yogyakarta: LESFI.

Asy-Syahrastani. 2006. Al-Milal wa al-Nihal: Aliran-aliran Teologi dalam Sejarah Umat Manusia (Edisi Lengkap), terj. Asywadie Syukur, Surabaya: PT. Bina IImu.

Corbin, Henry, History of Islamic Philosophy, terj. Liadain 
Sherrard dan Philip Sherrard, London \& New York: Islamic Publications dan The Institute of Ismaili Studies.

Cornell, Vincent J. (ed.). 2007. Voices of Islam: Volume I (Voices of Traditions), USA: Praeger Publishers.

Dahlan, Moh. 2012. "Nalar IImu Kalam Emansipatoris", Religi, vol. 3, no. 1.

De Boer, T.J., 1967. The History of Philosophy in Islam, tej. Edward R. Jones , B.D, New York: Dover Publications, Inc.

Erdem, H. Sabri. 2007. "On Some Theological Views of Abu Mansur al-Maturidi", Ilahiyat Fakultesi IImi Dergisi.

Fakhry, Majid. 2004. A History of Islamic Philosophy (Third Edition), New York: Columbia University Press.

Farida, Umma. 2014. "Membincang Kembali Ahlussunnah wa alJamaah: Pemaknaan dan Ajarannya dalam Perspektif Mutakallimin", Fikrah, vol. 2, no. 1.

Gibb, H.A.R., dkk,. 1991. The Encyclopaedia of Islam: Jilid 6, Leiden: E.J Brill.

Hamka. 2007. "Maturidiyah: Kelahiran dan

Perkembangannya", Jurnal Hunafa, vol. 4, no. 3.

Hasbi Ash Shiddieqy, Teungku Muhammad,. 1997. Pokokpokok Pegangan Imam Mazhab, Semarang: PT. Pustaka Rizki Putra.

Hatta, Mohammad. 2006. Alam Pikiran Yunani, Jakarta: UI Press.

Isik, Kemal. 1980. Maturidi'nin Kelam Sisteminde: Iman Allah ve Peygamberlik Anlayisi, Ankara: Futuvvet Yayinlari.
Izutsu, Toshihiko. 2008. God and Man in the Qur'an: Semantics of the Qur'anics Welthanschauung, Kuala Lumpur: Islamic Book Trust. 1994. Konsep Kepercayaan dalam Teologi Islam: Analisis Semantik Iman dan Islam, terj. Agus Fahri Husein, Yogyakarta: Tiara Wacana Yogya.

Karim, M. Nazir, 2004. Dialektika Teologi Islam: Analisis Pemikiran Kalam Syeikh Abdurrahman Shiddiq alBanjari, Pekanbaru: Kerjasama Nuansa dan SUSKA Press.

Lazar, Marius. 2015. "Islam: Faith and Practice", Analize: Journal of Gender and Feminist Studies, no. 4.

Leaman, Oliver dan Sajjad Rizvi,. 2008. "The Developed Kalam Tradition" dalam Tim Winter (ed.), The Cambridge Companion to Classical Islamic Theology, New York: Cambridge University Press.

Machasin. 1996. Menyelami Kebebasan Manusia: Telaah Kritis terhadap Konsepsi AlQur'an, Yogyakarta: Pustaka Pelajar.

Madani, Abdul Hai. 2011. "Freedom and Its Concept in Islam", IPEDR, vol. 17.

Martin, Richard C., dkk,. 2003. Defenders of Reason in Islam: Mu'tazilism from Medieval School to Modern Symbol, Oxford: Oneworld Publications. 2004. (ed.), Encyclopedia of Islam and the Muslim World: Volume 2 (M-Z), USA: Macmillan Reference.

Masturin, "Khazanah Intelektual Teologi Maturidiyah", Kalam: Jurnal Studi Agama dan 
Pemikiran Islam, vol. 8 , no. 1 Juni 2014.

Al-Maturidi, Abu Mansur Muhammad ibn Muhammad ibn Mahmud. 1970. Kitab al-Tawhid, tahqiq Fath Allah Khalif, Beirut: Dar al-Mashyriq.

Mufid, Fathul. 2013. "Menimbang Pokok-pokok Pemikiran Teologi Imam al-Asy'ari dan alMaturidi", Fikrah, vol. 1, no. 2.

Nasir, Sahilun A., 2010. Pemikiran Kalam (Teologi Islam): Sejarah, Ajaran dan Perkembangannya, Jakarta: Rajawali Pers. , 2005. "The Epistemology of Kalam of Abu Mansur alMaturidi", Al-Jami'ah, vol. 43, no. 2.

Nasr, S.H., tt. Islam: Religion, History and Civilization, HarperCollins e-books.

Nasution, Harun. 2012. Islam Ditinjau dari Berbagai Aspeknya: Jilid II, Jakarta: UIPress. 2006. Muhammad Abduh dan Teologi Rasional Mu'tazilah, Jakarta: UI Press. 1986. Teologi Islam: Aliran-aliran, Sejarah, Analisa dan Perbandingan, Jakarta: UI Press.

al-Nawawi, Imam. 2010. 40 Hadis Paling Populer, terj. Budiman Mustofa, Solo: Ziyad Visi Media.

Nor Ichwan, Mohammad,. 2005. "Dekonstruksi Teologi: Menuju Pemaknaan Teologi yang Membebaskan", Teologia, vol. 16, no. 1 .

Ozervarli, M. Sait. 1997. "The Authenticity of the Manuscript of Maturidi's Kitab al-Tawhid: A Re-examination", Islam Arastirmalari Dergisi, no. 1.
Pavlin, James. 2003. "Kalam Sunni dan Kontroversi Teologis", dalam S.H. Nasr dan Oliver Leaman (eds.), Ensiklopedi Tematis Filsafat Islam (Buku Pertama), terj. Tim Penerjemah Mizan, Bandung: Mizan.

Pojman, Louis P. 2001, Philosophy: The Pursuit of Wisdom 3rd, Canada: Wadsworth,.

Rahbar, Daud 1960. God of Justice: A Study in The Ethical Doctrine of The Qur'an, Leiden: E.J. Brill,

Rahman, Fazlur. 1979. Islam, USA: The University of Chicago Press. ,1984. Islam and Modernity: Transformation of an Intellectual Tradition, USA: The University of Chicago Press,. ,1980. Major Themes of the Qur'an, Minneapolis-Chicago: Biblioteca Islamica, , 2000. Revival and Reform in Islam: A Study of Islamic Fundamentalism, Oxford: Oneworld Publications.

Ramazan Basaran, Yasin. 2011. "The Idea Subjective Faith in al-Maturidi's Theology", Journal of Islamic Research.

Sheikh, M. Seed. 1962. Studies in Muslim Philosophy, Club Road, Lahore: Pakistan Philosophical Congress.

Syafii Ma'arif, Ahmad. 1985. Islam dan Masalah Kenegaraan: Studi tentang Percaturan dalam Konstituante, Jakarta: LP3ES.

Thomas, David. 2008. Christian Doctrines in Islamic Theology, Leiden \& Boston: Brill.

Wahid, Abdurrahman. 2006. Islamku, Islam Anda, Islam Kita: Agama 
Afrizal Mansur, Andi Saputra; Konsep Keadilan Tuhan: Studi Pemikiran Teologi Abu Mansur Al-Maturidi.

Masyarakat Negara Wahid Institute.

2007.“Universalisme

Islam dan Kosmopolitanisme

Peradaban Islam: Prolog", dalam Nurcholish Madjid, dkk, Islam Universal, Yogyakarta: Pustaka Pelajar.

Watt, W. Montgomery. 1985. Islamic Philosophy and Theology: An Extended Survey, Edinburgh: Edinburgh University Press.

Wojcik, Agata dan Lukasz Wojcik,. 2010. "The Sources of Religious and Political Power in Thought of Abu Mansur alMaturidi and Saint Thomas Aquinas: the Comparative Perspective", e-Makalat Mezhep Arastirmalari, vol. III, no. 2.

Zar, Abu, 2014. "Pemikiran alMaturidiyah dalam Pemikiran Islam", Jurnal Adabiyah, vol. 14, no. 2.

Zar, Sirajuddin, 2007. Filsafat Islam:

Filosof dan Filsafatnya,

Jakarta: PT. RajaGrafindo

Persada.

Zuhri, Amat, 2010. "Kecenderungan Teologi Maturidiyah Samarkand", RELIGIA, vol. 13, no.1. 